\title{
A participant observation approach to assessing the validity of Hofstede's national culture framework
}

\author{
Fred Hoffman, Mercyhurst University, fhoffman@mercyhurst.edu
}

\begin{abstract}
In a globalized economy, multinational corporations often have overseas locations and/or significant numbers of employees who may not have been socialized in the company's home country. By recognizing and acknowledging the implications of having been socialized by a national culture different from one's own, corporate leaders can better anticipate and respond to the attitudes and behaviors of those employees, to include those impacting information security within the corporation (Hoffman \& Skovira, 2020). One of the most widely used models for assessing and describing national culture is the theoretical framework developed by Hofstede (1980), whose six dimensions of national culture represent a useful tool for examining and understanding the attitudes and behavior of national cultural groups. This study used participant observation, an ethnographic methodology, to assess how Hofstede's Six Dimensions of National Culture apply to the observed attitudes and behavior of individuals raised and socialized in the Russian culture. Based on each of the six dimensions of Hofstede's study, the researcher took note of statements and behaviors by the ethnography participants and assessed how they aligned with Hofstede et al. (2010)'s characterization of Russian national culture.
\end{abstract}

Keywords: National culture, Hofstede, ethnography

\section{Introduction}

National culture-influenced attitudes and behaviors can impact an organization's information security (Hoffman \& Skovira, 2020). In fact, one of the findings reported by Geraskin, Krasnoborodko, Glebov, \& Piskureva (2015) after analyzing statistics related to security violations and incidents at Russian nuclear facilities (acquired from the Russian State Corporation Rosatom and Russian State Regulatory Agency Rostekhnadzor) was that "as many as $80 \%$ of the root causes of security violations are related to human error or other culture-related issues" (p. 332). In short: Culture matters. "Culture is one of the most significant relational properties of security networks" (Whelan, 2017, p. 113). The purpose of this study was to use an ethnographic approach to assess the validity of Hofstede et al. (2010)'s characterizations of Russian culture based on the Six Dimensions of National Culture derived from his Values Survey Module (VSM) research approach.

\section{What is culture?}

According to Hofstede et al. (2010), the term culture could be applied at the level of nations, societies, organizations, professions, and even individual families. Hofstede et al. (2010) described culture as "the collective programming of the mind which distinguishes the members of one human group from another" (p. 21). "Social scientists currently think of culture as shared knowledge and mutual expectations produced, disseminated, and reproduced among a network of interacting individuals" (Grossmann, Ellsworth, and Hong, 2012, p. 1). Geertz (1973) states, "it is through the flow of behavior - or, more precisely, social action - that cultural forms find articulation" (p. 17). Hofstede et al. (2010) points to the importance of symbols, heroes, ritual, and values, which he calls the "four manifestations of culture" (p 7). Behavior 


\section{Issues in Information Systems}

Volume 22, Issue 2, pp. 334-349, 2021

reveals culture, according to Geertz (1973), who explains that human beings are suspended in "webs of significance" (p. 5), and advocates for a semiotic approach to culture "to aid us in gaining access to the conceptual world in which our subjects live so that we can, in some extended sense of the term, converse with them" (p. 24).

\section{Hofstede et al. (2010)'s dimensions of national culture}

One of the most popular models used to assess and describe national culture, and to compare one national culture to another, is the theoretical framework developed by Hofstede (1980). Using survey data collected twice from 40 different countries, first in 1968 and then again in 1972, Hofstede (1980) analyzed the results of over 116,000 usable surveys to develop his framework. Hofstede (1980) asserted his research identified "four main dimensions along which dominant value systems in the 40 countries can be ordered and which affect human thinking, organizations, and institutions in predictable ways" (p. 11). Hofstede's (1980) original dimensions of national culture consisted of four indices: Power Distance Index (PDI), Uncertainty Avoidance Index (UAI), Individualism Index (IDV), and Masculinity Index (MAS). Hofstede later added a fifth dimension, Long-Term Orientation (LTO) (Hofstede, 1991), and subsequently a sixth, Indulgence Versus Restraint (IVR) (Hofstede et al., 2010).

Some of the researchers who applied one or more of Hofstede's six dimensions of national culture to compare information technology-related behaviors in two or more countries include Tang, Li \& Zhang (2016), Ifinedo (2014), Hovav \& D’Arcy (2012), Dinev, Goo, Hu, \& Nam (2009), Yoon (2009), Johnson et al. (2009), Schmidt, Johnston, Arnett, Chen, \& Xi' an (2008), Chen, Medlin, \& Shaw (2008), Waarts \& van Everdingen (2005), Veiga, Floyd, \& Dechant (2001), Milberg, Smith, \& Burke (2000), Ralston, Holt, Terpstra, \& Yu (1997).

\section{What is Russian culture?}

National culture is not necessarily defined by national borders. Naumov and Puffer (2000) note that "while Russian is the predominant culture, the Russian Federation consists of more than 100 national groups" (p. 717). Not all citizens of the Russian Federation grew up in the Russian culture; on the other hand, sizeable minorities in countries that were once part of the former Soviet Union definitely did. Franklin and Widdis (2006) note that that the Russian Federation is multi-cultural, and there are ethnic Russians residing outside of the boundaries of the Russian Federation. "The Russian language has developed the usage of two separate words (originally synonyms) to deal with this: rossiiskii and russkii. Both mean 'Russian', but rossiiskii refers to Rossiia, the geo-political entity (hence the imperial identity) while russkii is more narrowly ethnic and linguistic" (p. 5). The latter term applies to Hofstede et al. (2010)'s analysis, and to this study. Two additional relevant Russian words, narod and narodnost, refer to Russian concepts of the people (narod) and the Russian soul (narodnost) Devlin (2021). Hofstede et al. (2010) notes that whereas nations are a "recent phenomenon in human history," distinctive "ethnic, linguistic, and religious groups" within many countries have shown themselves ready to fight for recognition of their own identity" (p. 20-21).

Dranitsa (2012) surveyed 40 individuals to investigate cultural characteristics of the Russian business culture in accordance with Hofstede et al.'s (2010) national culture theory. Survey results indicated that for Russians, business relationships "are extremely significant" (Dranitsa, 2012, p. 4). Dranitsa (2012) found that Russian business culture is a mix of Asian and European cultures: "Our mentality is not 'oriental' in large measure, but we have not 'western' mentality either. We are in the middle of this extremity" (Dranitsa, 2012, p. 4). This assertion aligns with the sentiment expressed by Grachev and Bobina (2006), that Russia "has served as a bridge between Western and Eastern cultural traditions with a certain psychological dependence on both" (p. 68). To explore the emotional differences between Russian and American cultures, Grossmann, Ellsworth, and Hong (2012) compared how 69 Russian and 64 American college students responded when exposed to an identical set of 36 pictures, finding that, "Whereas Russians predominantly 


\section{Issues in Information Systems}

Volume 22, Issue 2, pp. 334-349, 2021

attended to negative pictures, Americans spent about the same amount of time looking at both type of stimuli" (p. 2). Naumov and Puffer (2000) used a 29-item questionnaire to survey 250 Russian respondents over nine months during 1995 and 1996, comparing survey responses for each of Hofstede's (1991) thenfive dimensions with Hofstede's (1991) own findings. Just five or six years after the collapse of the former Soviet Union, Naumov and Puffer (2000) found that, "the profiles of this younger generation tended to converge toward those in Western developed countries more than the other groups of Russians surveyed" (p. 717). Girlando and Eduljee (2010) found that while Russia and the U.S. have "deep cultural differences", research on those differences "has been hampered as data on Russia are sparse" (p. 268-269).

A review of the academic literature on Russian culture reveals the lack of ethnographic research specifically conducted to assess the valididity of Hofstede et al.'s (2010) assertions about Russian culture. The purpose of this study was to address that gap. "Ethnography is created when learned individuals enter into cultures or societies unlike their own, participate in societal life, and write their observations down" (Devlin, 2021, p. 1). Ethnography actually has a long history in Russia, dating back to the early 1700s, when Vasily Taishchev conducted one during the reign of Peter the Great (Devlin, 2021).

\section{Methodology}

\section{Participant observation}

For this study, the researcher used participant observation, an ethnographic technique, because it "relies heavily on up-close, personal experience and possible participation, not just observation" (Genzuk, 1999, p. 1). Participant observation was employed because "the researcher shares as intimately as possible in the life and activities of the people in the observed setting" (Genzuk, 1999, p. 2). According to Geertz (1973), there are two alternative perspectives the cultural researcher can adopt when analyzing the culture of a group: The emic, in which the researcher enters the culture being studied and experiences it from within the cultural group and from the perspective of its members, or the etic, in which the researcher takes the perspective of an observer who is outside the cultural group. Geertz's method for gaining an understanding a culture through was emic, as a participant observer. Geertz (1973) advocated for the participant observer approach to understand culture on the grounds that "it is through the flow of behavior - or, more precisely, social action - that cultural forms find articulation" (Geertz, 1973, p. 17). The benefit of the emic approach favored by Geertz is that because it requires the researcher to immerse him or herself in the cultural group and observe their behavior directly, the researcher doesn't rely on what individuals say they would do under certain circumstances; rather, the researcher can directly observe their actual behavior under those circumstances.

\section{Sample population}

The descriptors of the individuals listed below include: (1) Alphanumeric identifier; (2) gender (M/F); (3) age. Names have not been used to provide anonymity to group members. All participants (see Table 1) were raised and socialized in the Russian culture in either the Soviet Union or in the Russian Federation.

\section{Data collection places and times}

Data was collected over a period of six months during the latter half of 2016. Settings for these observations included multiple group interactions in such places as private homes, a Ukrainian Orthodox Church, a Russian supermarket outside Baltimore, and at a social club. This ethnography examines the behavior and interactions of a group of 14 people who had been raised and socialized in the Russian culture - a mix of Russians from Russia, and ethnic Russians and ethnic Ukrainians from Ukraine - all but two of whom now 


\section{Issues in Information Systems}

Volume 22, Issue 2, pp. 334-349, 2021

permanently reside in the United States, in an effort to identify behaviors that reflect not their citizenship, or their nationality, but rather their identity as revealed by observable indicators of their culture. Separate from identifiers like citizenship, nationality, religion, or even language, what do their behaviors reveal about them, and about the cultures which, according to Hofstede et al. (2010), programmed their minds (p. 4)?

Table 1. Ethnography participants' identifiers, gender, age, and description.

\begin{tabular}{|c|c|c|c|l}
\hline$\#$ & ID & Sex & Age & \\
\hline 1 & FL-1 & F & 54 & Emigrated to the U.S. from the Soviet Union (Moscow) in 1991 \\
\hline 2 & MP-1 & M & 27 & Emigrated to the U.S. from the Soviet Union (Moscow) in 1991 \\
\hline 3 & FO-1 & F & 15 & Emigrated to the U.S. from southern Ukraine \\
\hline 4 & FV-1 & F & 29 & Emigrated to the U.S. from Crimea in 2016 \\
\hline 5 & MB-1 & M & 30 & Emigrated to the U.S. from Crimea, 2016 \\
\hline 6 & MV-2 & M & 55 & Emigrated to the U.S. from Soviet Union, 1970s \\
\hline 7 & FI-1 & F & 53 & Emigrated to the U.S. from Russian Federation, early 1990s \\
\hline 8 & FL-2 & F & 79 & Russian citizen, visitor to the U.S. \\
\hline 9 & MS-1 & M & 69 & Russian citizen, visitor to the U.S. \\
\hline 10 & FI-2 & F & 50 & Emigrated to the U.S., early 1990s \\
\hline 11 & FN-1 & F & 30 & Emigrated to the U.S. from Russia, early 1990s \\
\hline 12 & MD-1 & M & 66 & Emigrated to the U.S. from Ukraine, early 1990s \\
\hline 13 & FN-2 & F & 58 & Ethnic Ukrainian (native Ukrainian speaker) bom and raised in the U.S. \\
\hline 14 & MV-3 & M & 40 & Emigrated to the U.S. from Ukraine, early 1990s
\end{tabular}

\section{How the U.S. and Russia scored}

As Figure 1 reveals, Russian and U.S. scores vary greatly on all six of Hofstede et al.'s (2010) national culture scores. As Borker (2017) observed, Russia receives "relatively high scores for PDI, UAI, and relatively low values for IDV, MAS and IVR" which is "the complete opposite of the United States, which has low PDI and UAI and high IDV, MAS and IVR" scores (Borker, 2018, p. 276). As a result of these radically different cultural scores, Russia and the U.S. have "deep cultural differences" (Girlando and Eduljee, 2010, p. 268-269). 


\section{Issues in Information Systems}

Volume 22, Issue 2, pp. 334-349, 2021

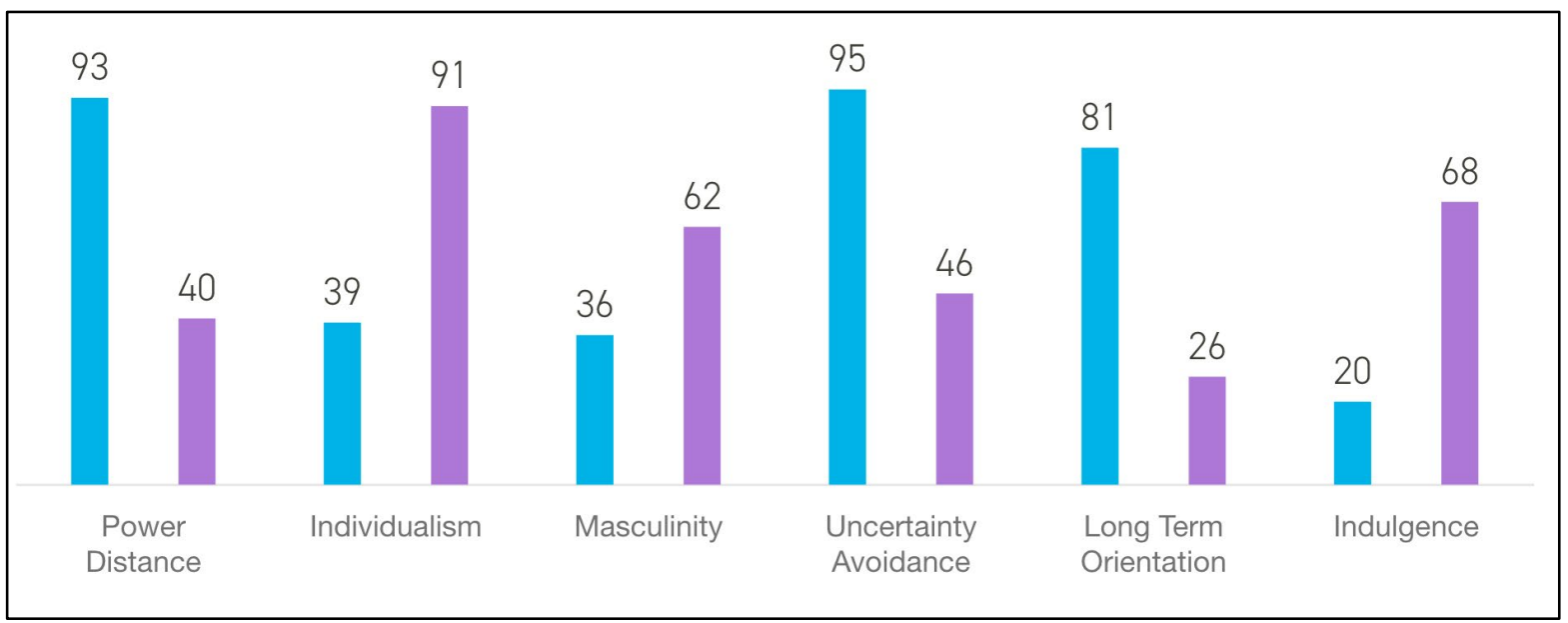

Figure 1. Russian (blue) and U.S. (purple) values on Hofstede et al.'s (2010) Six Dimensions of National Culture. Source: https://www.hofstede-insights.com/product/compare-countries/

\section{Results}

\section{Power Distance (PDI): Russia (93), U.S. (40)}

Power distance describes dependence relationships in a country. "Power distance can therefore be defined as the extent to which the less powerful members of institutions and organizations within a country expect and accept that power is distributed unequally" (Hofstede et al., 2010, p. 61). Hofstede et al.'s (2010) research revealed high power distance values for Russia. So did Grachev and Bobina (2006), whose analysis of results for Russia obtained by the Global Leadership and Organizational Behavior Effectiveness (GLOBE) research program, found Russian respondents scored "very high in Power Distance" (p. 74).

In fact, Russia earned the sixth highest score of 76 countries and regions Hofstede et al. (2010) studied throughout the world (p. 57-59). One of the attributes of a high power distance culture (like Russia) is popular acceptance of the power and prestige associated with one's position and status. Not only political leaders, but also bosses, older family members, coaches, and doctors receive greater deference than in a lower power distance culture (like the U.S.).

FV-1's trip to the ER. FV-1 and MB-1 described to FL-1 a recent trip they had made to the emergency room in Baltimore. FV-1 said she described to the doctor how she had an exceptionally sore throat, but the doctor misunderstood her and thought she had something lodged in her throat. As a result, the doctor initiated a protocol used when a patient has something lodged in their throat (CT scan and IV contrast). This misunderstanding, which FV-1 and MB-1 recognized right away, resulted in a large bill that FV-1 and MB1 would now have to pay. FL-1 asked FV-1, "Why didn't you tell the doctor that he had misunderstood you, and that you only had a sore throat?" FV-1 looked blankly at FL-1 and replied, that she "was afraid to say anything" because "he was a doctor." FV-1 and MB-1's silent acceptance of the erroneous assumption and treatment by the ER physician was consistent with what one would expect of people from a culture assessed to have a high power distance score. Their uncritical deference to the ER physician was likely due to several reinforcing, cultural factors: The physician was: (1) older than both FV-1 and MB-1, (2) an authority figure in a profession traditionally afforded great respect in the Ukrainian culture; (3) wearing a clinician's white lab coat; (4) adorned with the customary accoutrements identifying physicians in a hospital 


\section{Issues in Information Systems}

Volume 22, Issue 2, pp. 334-349, 2021

setting (identification badge, stethoscope, pocket protector with writing instruments, etc); (5) in a clinical setting; (6) working in one of the world's most prestigious hospitals; (7) surrounded by other medical professionals whose verbal communication ("Dr. So-and-so, this patient...") and deferential behavior made his elevated status clear.

Of course, all bosses sleep with their secretaries. Three generations of males and females raised in Russian culture (FL-1, FO-1, MP-1, MS-1, and FL-2) were sitting at the kitchen table, watching an American TV news show in which commentators were discussing different candidates in the 2016 presidential election in the U.S. One of the commentators said something disparaging about something a particular candidate had said in the past. MS-1, exasperated, blurted out, "What's the big deal about what he said? All powerful men talk like that. And all bosses sleep with their secretaries." He shrugged his shoulders and added, "This is normal." Neither MS-1's wife, daughter, or granddaughter disagreed with, or seemed visibly shocked by, his statement. An American listening in on the conversation might have been tempted to say, "Oh, that is such a male chauvinist thing to say!" However, that listener's outrage would have been misplaced, because what MS-1 was expressing was not sexism, but something else entirely. Had he said, "Of course, all men sleep around," that would have been a gender-specific observation. Instead, the relationship he described was between a "boss" and a "secretary", which is a power relationship.

Children should not interrupt. FL-2, MS-1, FL-1, and FO-1 were having a conversation in Russian. MS-1 criticized FL-1's fashion sense and physical appearance, suggesting to her that she needed to "dress better" and take better care of her physical appearance. FO-1 interjected that her Mom, in fact, happens to have very good fashion style; MS-1 then chastised FO-1, telling her that, "children should not interrupt an adult conversation." FO-1, who almost certainly would have angrily stormed out of the room and barricaded herself in her room if an American adult said something like that to her in English, said and did nothing at all in response. Instead, she remained seated at the table, smiling, and behaving as if nothing at all had just happened. FO-1's unflinching acceptance of an admonishment from her grandfather is consistent with FO1 's understanding of the Russian family paradigm, in which parents and (especially) grandparents are afforded a very high degree of respect.

See what you can do when you're not so fat? FL-1 was watching FO-1 perform at an acrobatic gymnastics, or acro, competition. Diagonally across from her, on the other side of the match, were her coaches, MD-1 and his Russian female assistant. MD-1 was a Russian-speaking Ukrainian from Odessa, a former tank driver in the Soviet Army who had become an internationally-known acro coach before emigrating to the U.S. in the 1990s. His assistant was an ethnic Russian from Russia, a very successful, professional gymnast who emigrated to the U.S. around a decade ago. MD-1's acro gym had an equal number of American students and students from Russian or (predominantly) Russian-speaking families. FO-1 had started acro gymnastics within months of arriving in the U.S. at the age of ten; in her first year, she and her partner had taken sixth place at the Acro Nationals competition in Kentucky. MD-1 treated his American and Russian/Ukrainian students quite differently; he was more encouraging and demonstrably encouraging of his American students, and harsher and sterner towards his Russian/Ukrainian ones. In recent weeks, MD1 had scolded FO-1 for gaining some weight, telling her (in Russian) that she was "fat" (tolstyy). On this day, FO-1 and her partner executed their acro routine almost flawlessly, earning their highest score ever. As FL-1 congratulated FO-1, MD-1 jogged over from his coach's position on the other side of the mat. 


\section{Issues in Information Systems}

Volume 22, Issue 2, pp. 334-349, 2021

Smiling broadly, he hugged FO-1 and loudly proclaimed (in Russian), "See what you can do when you're not so fat!" FO-1 beamed and nodded vigorously in agreement. FL-1 beamed in response.

FO-1's smiling acceptance of her male coach's backhanded compliment ('See what you can do when you're not so fat!") was likely not circumstantial, or due to the fact that the coach was male, or older, but because he was the head coach, an adult occupying a position of authority that commands considerable respect in the Russian culture. This also explains why this coach was soft and encouraging (and spoke English) to his American students but was stern, brusque, and infrequent in his praise of Russian-speaking students. Interestingly enough, none of the Russian-speaking students ever complained about this different treatment.

\section{Individualism-Collectivism (IDV): Russia (39), U.S. (91)}

The individualism versus collectivism index concerns the role (and importance) of the individual as compared to the group. Hofstede et al.'s (2010) individualism index contrasts Collectivist societies with Individualist ones. According to Hofstede et al. (2010), the U.S. is a more Individualist society, and Russia a more Collectivist one. In fact, Hofstede et al. (2010) found that Russia scores "considerably more collectivist than do Western countries" (p. 125). Whereas Americans socialized in an individualist culture take pride in rugged individualism and the freedom of personal choice, Russians socialized in a collectivist culture assign far greater importance to conforming to group norms and following the rules.

The social movement. FL-2 and MS-1 were chastising FL-1 for having too many cats in the house. "Two dogs and two cats is normal; but nine cats? What normal person does this?" FL-2 asked. FL-1 explained that while four of the cats were indeed family pets, the other five were all foster cats. FL-1 further explained that she and FO-1 are both part of an animal rescue group that traps, neuters and releases adult feral cats, and captures kittens who are neutered, tested for feline leukemia and other maladies, and then socialized for adoption. Hearing this explanation, FL-2 and MS-1 immediately changed their tune: Both effusively praised FL-1 for being part of "a social movement" that was "noble" and "requiring such sacrifice". They never again said anything critical about FL-1 having nine cats in the house.

Every day is Halloween. FL-1 was talking outside her house with several of her female American neighbors about Halloween, discussing with them how they would decorate their houses, what costumes their children would wear, what kind of candy they planned to give out to trick-or-treaters. The conversation turned to personal remembrances of Halloweens past. One of the women asked FL-1, "So, did you have Halloween growing up in Russia?" Without hesitation, FL-1 replied, "When I lived in Russia, every day was Halloween." She explained to her American friends that, in Soviet times, people always had to pretend to be something they weren't, just to avoid sticking out and running afoul of "the system". Being different was not only discouraged, it was dangerous.

\section{Masculinity-Femininity (MAS): Russia (36), U.S. (62).}

Hofstede et al. (2010)'s Masculinity-Femininity dimension assesses a cultural group's attitude toward workrelated goals. "A society is called masculine when emotional gender roles are clearly distinct: men are supposed to be assertive, tough, and focused on material success, whereas women are supposed to be more modest, tender, and concerned with the quality of life. A society is called feminine when emotional gender roles overlap: both men and women are supposed to be modest, tender, and concerned with the quality of 


\section{Issues in Information Systems}

Volume 22, Issue 2, pp. 334-349, 2021

life" (Hofstede et al., 2010, p. 140). Although Russia scores high on power distance, its scores also establish it as a feminine culture. Wolf and Stankovic (2015) describe the interaction between Russia's high power distance score and feminine culture: While high power distance accounts for Russia's "autocratic management style" (p. 12), Russia's feminine culture results in company owners playing "a paternalistic role", with the owner being "the most influential (powerful) person in the organization" (p. 12). Among Russians, "Authoritarian leadership is expected and well-accepted" (Wolf and Stankovic, 2015, p. 13).

Sending a cop over to discipline a kid. FL-1 said that, in some respects, the police in the U.S. were "not as helpful" as they might be in Russia under similar circumstances. For example, she said, she wanted to hire a policeman to come and tell her daughter to stay away from some "hooligan" male friend of hers; she wanted a policeman to come and tell her daughter that this hooligan friend was under police surveillance, and that if she wanted to avoid being surveilled by the police, she would need to steer clear of him. "In Russia, it would be no big deal to pay a cop a few bucks to come and do something like that. Half the cops would do it for free. Everyone there knows that adults do what they have to do to protect kids from themselves. Here, no cop would do it, and you'd probably get sued just for asking them."

Psychiatrists are too easy on American kids. FV-1, MB-1, and FL-1 were discussing health care in the United States and "back home". FL-1 opined that, in some respects, health care was better in Russia. In addition to the overall "wisdom of the doctors" in Moscow, she said, Russian psychologists and counselors were "much better at dealing with problem children". FL-1 criticized the way American counselors worked with troubled children: Not talking with parents first about the behavioral issues that prompted the parents to bring their child in for counseling in the first place. Not having the parents and the child together, early on, for a group session. "The counselors here just pat the children on the head, and only learn the child's side of the story." FV-1 and MB-1 shook their heads, indicating their agreement with the absurdity of such an approach.

\section{Uncertainty Avoidance (UAI): Russia (95), U.S. (46)}

Uncertainty avoidance addresses the way individuals in a particular national culture handle uncertainty, and the degree to which uncertainty causes anxiety (Hofstede et al., 2010). According to Hofstede et al. (2010), Russian culture earned a very high score (95) for uncertainty avoidance, which suggests Russians prefer predictability over uncertainty, and the known over the unknown. With respect to Russia, Wolf and Stankovic (2015) describe how the "main role of numerous administrative workers... is to establish rules and formal procedures in order to provide a predictable and stable working environment where there is nothing left to random for an unpredicted change" (p. 10). In addition, their study showed that "Russian management doesn't accept changes gladly. They are especially skeptic toward decisions that haven't been proved in practice" (p. 10).

The (unwritten) Toyota rule. Over the years, the researcher had heard countless Russian expatriates joke how it was "an unwritten rule" that all Russians who emigrate to the United States must buy a Toyota. In fact, there was a pecking order that identified one's rising status in the United States: One starts with a used Toyota Corolla, moves up to a new Corolla, then to a used Camry, then on to a new Camry. After hearing this a number of times, the researcher started paying attention to the number of Russian and Ukrainian people who owned a Toyota - and discovered there actually seemed to be some basis for this stereotype. In 


\section{Issues in Information Systems}

Volume 22, Issue 2, pp. 334-349, 2021

September 2016, a Russian immigrant, a professional woman in her late 30s who had immigrated from Russia a decade or so ago, came and interviewed at the researcher's company. After the interview, she and the researcher chatted casually about various topics. She mentioned that she owned her own home in a predominantly Russian enclave outside Baltimore; knowing the area, the conversation turned to stores and restaurants in the area. As the researcher walked the interviewee out of the building and into the outside parking lot, she mentioned she had just bought a new car. The researcher jokingly asked, "It's not a Toyota Camry, is it?" "How did you know?" she asked, a shocked look on her face. Indeed, at the far end of the lot was a brand-new Toyota Camry. The researcher explained what he had heard about Russians and Toyotas and shared some personal observations over the years that seemed to affirm this stereotype. The interviewee laughed and said, "You know, actually, it's true." She admitted that many of her Russian friends drove Toyotas but could not recall them overtly influencing her car buying decision in any way. She said she felt a little embarrassed knowing that she was reinforcing a stereotype; the researcher jokingly reassured her that she was, in fact, a "rebel" because her Camry was midnight blue; almost all Russians with Toyotas he knew preferred white, beige, or black. "I guess you can take the girl out of Russia, but you can't take the Russian out of the girl," she said with a wink as she climbed into her car.

Preparing for the cleaners. A day or two before the professional house cleaners would come to her house, FL-1 would tell her children to tidy and clean their rooms because, "The maids are coming tomorrow!" When the researcher pointed this tendency out to FL-1's friend FI-1, FI-1 laughed and said, "You know, I do exactly the same thing. It's such a Russian thing. We probably clean more in preparation for the cleaning team coming than if we just cleaned our house ourselves."

Another aspect of uncertainty avoidance that Hofstede et al. (2010) talks about is how people express themselves. "Family life in high-UAI societies is inherently more stressful than where UAI is low. Feelings are more intense, and both parents and children express their positive sentiments as well as their negative sentiments more emotionally." (Hofstede et al., 2010, p. 202). Hofstede et al. (2010) also found that "in high-UAI countries people showed a negative tendency in describing their work and life situation" (p. 205). Based on Hofstede et al.'s (2010) observations, and given Russia's much higher UAI score (95), someone socialized in the United States (46) might consider certain statements by Russians to be overly pessimistic and negative.

Negative by Nature. FL-1 was criticizing her son, MP-1, because her computer was running slowly. MP-1 had replaced the hard drive on her seven-year-old MacBook with a solid state drive (SSD), but the actual culprit was not the hard drive, but rather that her Internet connection was very slow. "Ever since you played around with my computer, it has been so slow!" she declared to MP-1. The researcher asked her why she had been so accusatory, since his replacement of her hard drive had nothing whatsoever to do with her Internet connectivity speed. The researcher pointed out that she was blaming him for something that was not his fault and asked whether the programs on her computer were running better since he replaced the SSD. She said they were, in fact, running much better. "Then why be so negative about what he did with your computer?" She thought about it a moment, shrugged, and said, "It's part of the culture I was raised in. We are all just negative by nature." 


\section{Issues in Information Systems}

Volume 22, Issue 2, pp. 334-349, 2021

Assuming the Worst. More than once, FL-1 would complain about one ailment or another and attribute the symptoms to possibly being indicative of some horrendous ailment - breast cancer, a brain tumor, etc. After one trip to the doctor where her extreme self-diagnosis was ruled out, a very relieved FL-1 explained, "In my culture, everyone does this. We always assume the worst but hope for the best. Because it is better to expect for the worst and have something better come about, than to assume the best and be devastated by something less positive as an outcome."

\section{Long-Term Orientation (LTO): Russia (81), U.S. (26)}

Long-term orientation, Hofstede et al.'s (2010) fifth dimension of national culture "stands for the fostering of virtues oriented toward future rewards - in particular, perseverance and thrift. Its opposite pole, shortterm orientation, stands for the fostering of virtues related to the past and present - in particular, respect for tradition, preservation of 'face,' and fulfilling social obligations" (Hofstede et al., 2010, p. 239). Russia (81) is a long-term oriented culture, and the U.S. (26) is a short-term oriented one. Bigge and Thoren (2016) describe Russian culture, with its relatively high LTO score of 81, as pragmatic. "Russia has a pragmatic mindset... Societies with pragmatic orientation, not only rely on the present situation, time and context but also on investing in modern education as well as future prospects. This makes the Russian society value thriftiness and perseverance," (Bigge and Thoren, 2016, p. 17)

Telephone etiquette. In the U.S., a telephone call between friends commonly winds down gradually, with one or more meaningless expressions at the end - "good talking with you", "thanks for calling", et cetera before the call finally terminates with goodbyes. Not so with Russians, especially those who had lived in the Soviet Union. MB-1 and FV-1 explained that their own parents were like that on the phone, but they themselves weren't. They explained that older Russians are like this on the phone because they grew up in communal apartments where: (1) The only phone on the floor was in the hallway; (2) everyone on the floor could hear the conversation being conducted on the phone; (3) an operator - and usually an intelligence service or two - was listening in. "We all learned to say what we had to say and then get off the phone as quickly as possible," MB-1 said.

\section{Indulgence versus Restraint (IVR): Russia (20), U.S. (68)}

Hofstede et al. (2010) states, "Indulgence stands for a tendency to allow relatively free gratification of basic and natural human desires related to enjoying life and having fun. Its opposite pole, restraint, reflects a conviction that such gratification needs to be curbed and regulated by strict social norms" (p. 281). In addition, "Indulgence versus restraint shows the conflict between a need for freedom of speech versus a need for order" (Hofstede et al., 2010, p. 413). The U.S. is very Indulgent (68), while Russia is considerably more Restrained (20). As Hofstede et al. (2010) asserted, "More indulgent societies have more optimistic people, and vice versa" (p. 290). Even after the demise of the Soviet Union, and despite significant economic and quality-of-life improvements in Russia between 1998 and 2008, Hofstede et al. (2010) noted, "the dismally low happiness levels that characterized them at the outset of the period remained virtually unchanged a decade later" (p. 290). Hofstede et al. (2010) relates a story about the U.S. hamburger chain McDonald's experience when it expanded its operations into Russia. Part of McDonald's corporate culture is that its employees smile broadly at patrons, something the company trained its Russian employees to do. Unfortunately, broadly grinning employees are received with shock in the Russian culture (p. 294). A similar distinction between Russian and American cultures is the lack of smiling in photographs. (Mention Larissa and her fake smiles, used to poke fun.) "Over in Russia, a stern face is a sign of seriousness, and it only seems to bolster the high rating that Vladimir Putin has always enjoyed" (Hofstede et al., 2010, p. 295). As Grossman, Ellsworth, and Hong (2012) asserted, "Americans may feel that they should say that 


\section{Issues in Information Systems}

Volume 22, Issue 2, pp. 334-349, 2021

they are happy, look happy, and act happy in order to show that they are successful members of their culture. Russians may emphasize darker emotions in order to look like good Russians. Any or all of these processes may contribute to cultural differences in emotion" (p. 5).

I am fine. When FL-2 and MS-1 flew into town, the researcher picked them up and took them to their hotel. During the drive, MS-1 described to me their "strange experience" at the U.S. embassy in Moscow, where they had applied for a visa. "This stupid guy there, with this big smile on his face, kept asking me questions about my scientific background. Always smiling, like an idiot." Soon thereafter, we departed for a nearby restaurant. Since there was a 20 -minute-long wait for a table, we decided to sit outside and enjoy the unseasonably warm weather. As MS-1 and FL-2 seated themselves on a concrete bench, the researcher asked FL-2 how she was doing. "I am fine! Since I am here in America, if someone asks me how I am, I am fine. Even if I have been hit by a truck, I am still fine." MS-1 laughed knowingly. She explained, "In Russia, if someone asks how you are, you reply, 'Normalno'. Everything is normal. But since I am here, I must smile and say, "fine"'. The researcher related to them a conversation he had with his wife in Moscow, when she had told him that Americans in Russia who smile all the time are perceived as insincere. MS-1 laughed and said, "Of course! In Russia, if you smile all the time, people think you're an idiot. Just like that guy at your embassy in Moscow." At different times and in different conversations, FL-1, FL-2, MS-1, and other participants all made reference to "smiling Americans". Facial expressions and smiling are explicitly addressed by Hofstede, who mentioned that, "Over in Russia, a stern face is a sign of seriousness" (Hofstede et al., 2010, p. 295). Hofstede et al. (2010) could have taken that observation one step further, and added that in Russia, excessive smiling is apparently associated with drunks, imbeciles, and Americans.

$A$ visit to the Russian Store. A preference for the familiar and predicable in Russian culture was abundantly evident during a visit to the local Russian store in Reisterstown, Maryland. Located in a Baltimore suburb heavily populated by Russian émigrés, the medium-sized Russian supermarket was filled with unsmiling shoppers and staff. FL-1 picked up a box of tea that she associated with her childhood in Russia. There were many brands of tea on the shelf, but this particular brand caught her eye. "This stuff tastes terrible, but it's familiar. It's a taste from the past. So, people here buy it," she explained.

Another distinctive aspect of Russian culture concerns attitudes toward free speech. As Hofstede et al. (2010) explains, Russians are less insistent on free speech than are many other nationalities. "Percentages of respondents who chose freedom of speech as the first national goal range from 36.6 in the Netherlands to 1.5 - the lowest in the world - in Russia... This finding explains why such a high percentage of Russians do not mind being governed by autocrats: in a restrained society with large power distance, authoritarian rule can be well accepted" (Hofstede et al., 2010, p. 295). This may help explain why FO-1 did not bat an eye when admonished by her grandfather (in Russian) that she needed to keep quiet and not offer her opinions during an adult conversation.

\section{Discussion}

\section{Limitations}

The intent of this study was to employ participant observation to assess the validity and applicability of Hofstede et al.'s (2010) characterizations about Russian culture. While this study proved useful, there were five recognized limitations:

- First, the relatively limited number of participants limits the generalizability of the findings to other, similar groups. 


\section{Issues in Information Systems}

Volume 22, Issue 2, pp. 334-349, 2021

- Second, the researcher did not join an established cultural group, or randomly recruit ethnography participants. All of the participants participating in this study were known to the researcher and, in most cases, to one another.

- Third, the researcher was not immersed in this group in that way that Geertz (1973) would have described as emic, where the researcher enters the culture being studied and experiences it from within the cultural group and from the perspective of its members. The researcher was only with the ethnography participants, intermittently, over a period of six months. This stands in stark contrast to Geertz' (1973) own emic experience with a Javanese tribal group, with which he lived and consistently interacted for a much longer period of time.

- A fourth limitation in the study is the difference in experiences between participants who had been raised and socialized in the former Soviet Union and those whose socialization occurred in the postSoviet states of Russia and Ukraine. Russian culture, and Russian life, was different during Soviet times than it was in the years after 1991, when the Soviet Union collapsed. Less well understood in the West was the cultural impact of the Yeltsin years (1991-2000), that decade between the collapse of the Soviet Union and the rise of Vladimir Putin, a period Rethmann (1997) described as "the lived reality of poverty, agony, and displacement," that "manifested corporeally in shaking, exhaustion, weariness, and drinking" (Rethman, 1997, p. 771). The Soviet, Yeltsin, and Putin years all had their unique impact on the acculturation of Russians; a more nuanced ethnography with a larger sample population could examine precisely what those impacts may have been.

- A final limitation of the study was the researcher's own linguistic limitations in the Russian language. Although the researcher spoke Russian well enough to understand conversations, he did not have the linguistic aptitude to ask the participants, in Russian, what they meant when they said this or that. An ethnographic study of this kind would best be conducted by a fully bilingual researcher.

\section{Bracketing, keying, and code switching}

For people raised and socialized in one culture who then find themselves transplanted into another (and very different) culture, the transition can sometimes be perplexing. Some of the techniques that aid in the back-and-forth transitions are informing objects, bracketing, keying, and code switching. An examination of how FL-1 and FO-1 behaved during an Orthodox Christian church service may be helpful in explaining the function and utility of these techniques.

\section{Orthodox church culture}

Based on culture and traditions dating back two millennia, Orthodox church services are replete with distinctive social artifacts, informing objects, rituals, and behaviors. The orthodox church culture is separate from, but co-exists with, the national culture of those study participants who were Orthodox Christians. The purpose of this study was to assess how Hofstede et al.'s (2010) Six Dimensions of National Culture apply to the attitudes and behavior of individuals raised and socialized in the Russian culture. However, what became apparent to the researcher during this study was that Orthodox Christian participants were also conditioned by, and conformed to, cultural influences of the Orthodox Church. That conditioning is facilitated by such things as informing objects, bracketing, and keying, as described below. 


\section{Issues in Information Systems}

Volume 22, Issue 2, pp. 334-349, 2021

For example, the priest's processional entrance signifying the start of the Orthodox church service, and also his ceremonial departure, combined with his use of informing objects (his priestly vestments, carrying the Bible), were examples of what Goffman (1974) describes as bracketing, such as when someone using a gavel to call a meeting to order and then uses it again to adjourn it. In between the entry and departure processionals, parishioners not only engaged in a succession of standard, familiar rituals and behaviors, but refrained from others. While it was perfectly acceptable (if not half-expected) for elderly men at one particular table in the church's fellowship hall table to pull out a flask, take a swig, and pass it to someone else, this behavior would have been regarded a scandalous, or worse, had it occurred in church during the mass.

Not only was the mass bracketed by the priest's ceremonial entry and departure processionals, but throughout the mass itself there were a number of actions that represented what Goffman (1974) refers to as keying. Towards the end of the mass, the priest picked up an ornate Bible and an icon and assumed a standing position in the center of the church. This cued the parishioners that it was time to leave their pews, line up, and wait their turn to kiss the Bible and the icon. In similar fashion, other keying statements or actions indicated when they should leave their pews for communion, sit down to listen to the sermon, or fish their wallets out of their pockets in anticipation of the soon-to-appear offering plate. Goffman (1974) uses the term frame to describe "a strip of activity [which] will be perceived by its participants in terms of the rules or premises of a primary framework" (p. 247). Within the larger frame of the mass itself, there are numerous sub-frames, each bracketed by keying actions, that keep parishioners aware of precisely "what it is that is going on here" (Goffman, 1974, p. 8).

After attending the Orthodox church service, FL-1, FO-1, and the researcher had the opportunity to speak with MV-3, a native Ukrainian priest who spoke excellent (but noticeably accented) English. Upon learning that the researcher was a recently retired U.S. Army officer, MV-3 immediately switched from celestial to geostrategic matters, asking the researcher for his opinion about the U.S. government's support for Ukraine's efforts to defend itself against Russia. When the conversation shifted, so too did MV-3's body language and phraseology. According to Kuhn (1974), for whom paradigms are a community of practice and discourse, MV-3's sudden mental transition from his role as priest of his Ukrainian Orthodox congregation to Army Reserve officer swapping stories with a fellow Reserve officer represented a clear, and abrupt, paradigm shift. From that moment forward, not only was MV-3's speech suddenly peppered with terms and phrases used within the culture of the U.S. Army, but even his stance and body language visibly changed as well. As he made the mental transition from one paradigm (parish priest) to another (Army Reserve officer and chaplain), this was an example of what Heller and Pfaff (2008) refer to as code switching. In one moment, MV-3 was an orthodox priest; in the next, he was an Army Reserve officer.

Code switching can involve not only body language and speech, but so much more. For example, on the day before FL-1's mother and stepfather came to visit from Russia, FO-1 spent eight hours in the kitchen preparing four different Russian specialty dishes, each of them from scratch: Borscht, vareniki, Olivaer salat, vinegret. While cooking, FO-1 wore a Russian apron and had a kerchief on her head. On the kitchen TV, a Russian-language TV sitcom was playing. Every burner on the stove had a pot with something cooking in it. FO-1's code switching was complete. 


\section{Issues in Information Systems}

Volume 22, Issue 2, pp. 334-349, 2021

\section{Conclusions}

The anecdotes shared in this document represented just a fraction of those experienced by the researcher during this study. Those chosen for inclusion in this document illustrate examples of situations where, in the estimation of the researcher, participants expressed attitudes or demonstrated behaviors that related in some way to one or more of Hofstede et al.'s (2010) dimensions of national culture. As a prologue to this study, it should be mentioned that FV-1 and MB-1 bought themselves their first used car shortly after this study concluded. It was, as one might now expect, a used Toyota sedan.

\section{References}

Bigge, V., and Thoren, M. (2016). One hand washes the other: A multiple Case Study about the mystery of blat and how it influences Swedish companies in Russia.

Borker, D. R. (2017). Russia and Ukraine: A comparison of cultural accounting orientation. The Business \& Management Review, 8(4), 269.

Chen, C., Medlin, B., \& Shaw, R. (2008). A cross-cultural investigation of situational information security awareness programs. Information Management \& Computer Security, 16(4): 360-376. doi.org/10.1108/09685220810908787

Devlin, M. R. (2021). Ethnography, folklore, Afanasev, and Russian self-identity. Inquiries Journal, 13(04). http://www.inquiriesjournal.com/articles/1896/ethnography-folklore-afanasev-andrussian-self-identity

Dinev, T., Goo, J., Hu, Q. \& Nam, K. (2009). User behavior towards protective information technologies: The role of national cultural differences, Information Systems Journal, 19(4), 391-412.

Dranitsa, A. A. (2012). Russian business culture according to G. Hofstede methodology. Journal of Economics and Social Sciences, (1), 1-4.

Franklin, S., \& Widdis, E. (Eds.). (2006). National identity in Russian culture: An introduction. Cambridge University Press.

Geertz, C. (2000). The interpretation of cultures. New York: Basic Books.

Genzuk, M. (2003). A synthesis of ethnographic research. Occasional Papers Series. Center for Multilingual, Multicultural Research (Eds.). Center for Multilingual, Multicultural Research, Rossier School of Education, University of Southern California. Los Angeles, 1-10.

Geraskin, N. I., Krasnoborodko, A. A., Glebov, V. B., \& Piskureva, T. A. (2015). Nuclear security culture enhancement: the role of culture coordinators at Russian nuclear sites. Defense \& Security Analysis 31(4), 330-345. doi:10.1080/14751798.2015.1087103

Girlando, A. P., \& Eduljee, N. B. (2010). An empirical investigation of the malleability of Hofstede's cultural dimensions: The case of the United States and Russia. Journal of Transnational Management, 15(3), 265-289. 


\section{Issues in Information Systems}

Volume 22, Issue 2, pp. 334-349, 2021

Grachev, M. V., \& Bobina, M. A. (2006). Russian organizational leadership: Lessons from the GLOBE study. International Journal of leadership studies, 1(2), 67-79.

Goffman, E. (1974). Frame analysis: An essay on the organization of experience. Boston: Northeastern University Press.

Grossmann, I., Ellsworth, P. C., \& Hong, Y. Y. (2012). Culture, attention, and emotion. Journal of Experimental Psychology: General, 141(1), 31.

Heller, M., \& Pfaff, C. W. (2008). Code-switching. In Kontaktlinguistik (pp. 594-609). De Gruyter Mouton.

Huntington, S. P. (1993). The clash of civilizations. Foreign Affairs, 72(3), 22-49.

Huntington, S. P. (1996). The clash of civilizations and the remaking of world order. New York: Simon \& Schuster.

Hoffman, F., \& Skovira, R. J. (2020). The organizational security index: A tool for assessing the impact of national culture on information security attitudes in Slovenia and the United States. Issues in Information Systems, 21(3), 95-104.

Hofstede, G. (1980). Culture's consequences: International differences in work-related MV-2ues. London: Sage.

Hofstede, G. \& Hofstede, G. J. \& Minkov, M. (2010). Cultures and organizations: Software of the mind. New York: McGraw-Hill.

Hovav, A., \& D'Arcy, J. (2012). Applying an extended model of deterrence across cultures: An investigation of information systems misuse in the U.S. and South Korea. Information \& Management, 49(2), 99-110. doi:https://doi.org/10.1016/j.im.2011.12.005

Ifinedo, P. (2014). The effects of national culture on the assessment of information security threats and controls in financial services industry. International Journal of Electronic Business Management, 12(2), 75-89.

Johnston, A., Warkentin, M., and Luo, X. (2009). National culture and information privacy: the influential effects of individualism and collectivism on privacy concerns and organizational commitment, in Proceedings of the International Federation of Information Processing (IFIP), International Workshop on Information Systems Security Research, Cape Town, South Africa, pp. 88-104.

Katan, D. (2009). Translation as intercultural communication. The Routledge companion to translation studies, p. 74-92.

Krichevsky, Lev (1997), "Ethnicity line axed from Russian passports," Jewish Weekly.com, 31 October 1997, URL: http://www.jweekly.com/article/full/6918/ethnicity-line-axed-from-russianpassports/

Kuhn, T. S. (1974). Second thoughts on paradigms. The structure of scientific theories, 2, 459-482. 


\section{Issues in Information Systems}

Volume 22, Issue 2, pp. 334-349, 2021

Milberg, S., Smith, H. J. \& Burke, S. (2000). Information privacy: corporate management and national regulation, Organization Science, 11(1), 35-57.

Naumov, A., \& Puffer, S. (2000). Measuring Russian culture using Hofstede's dimensions. Applied psychology, 49(4), 709-718.

Ralston, D. A., Holt, D. H., Terpstra, R. H., \& Kai-Cheng, Y. (1997). The impact of national culture and economic ideology on managerial work values: A study of the United States, Russia, Japan, and China. Journal of International Business Studies, 177-207.

Rethmann, P. (1997) Chto Delat'? Ethnography in the post-Soviet cultural context. American Anthropologist 99(4), 770-774.

Schmidt, M. B., Johnston, A. C., Arnett, K. P., Chen, J. Q. \& Xi'an, S. L. (2008). A cross-cultural comparison of US and Chinese computer security awareness. Journal of Global Information Management, 16(2), 91-103.

Tang, M., Li, M., \& Zhang, T. (2016). The impacts of organizational culture on information security culture: A case study. Information Technology \& Management, 17(2), 179-186.

Veiga, J. F., Floyd, S., \& Dechant, K. (2001). Towards modelling the effects of national culture on IT implementation and acceptance. Journal of Information Technology, 16(3), 145-158.

Waarts, E., \& Van Everdingen, Y. (2005). The influence of national culture on the adoption status of innovations: An empirical study of firms across Europe. European Management Journal, 25(6), 601-610.

Whelan, C. (2017). Security networks and occupational culture: understanding culture within and between organizations. Policing and Society, 27(2), 113-135.

Wolf, K. J., \& Stankovic, M. J. (2015) How does a Swiss watch run in Russia? Eco-worldwide.com.

Yoon, C. (2009). The effects of national culture values on consumer acceptance of e-commerce: Online shoppers in China. Information \& Management, 46(5), 294-301. 